\title{
Adaptation of Small and Medium-sized Enterprises During the COVID-19 Pandemic
}

\author{
Natalia Neklyudova ${ }^{1, *}$ \\ ${ }^{1}$ Institute of Economics, Ural Branch of the Russian Academy of Sciences, 29, Moskovskaya St., 620014, Ekaterinburg, Russia
}

\begin{abstract}
The article analyses static data that show the deterioration of the situation of SMEs around the world, both in developed and developing countries. Measures taken by governments to support SMEs and overcome the crisis were considered in the analysis. In most cases, they turned out to be insufficient to help reach the pre-pandemic economic level. The article also confirms that the self-employed and female entrepreneurs have suffered most. Industries such as tourism, construction industry, wholesale and retail trade, real estate, and services have suffered major loss.
\end{abstract}

Keywords: SMEs; pandemic; crisis; COVID-19

\section{Introduction}

Last year, many enterprises around the world were forced to close their operation in relation to to the COVID-19 pandemic, and those that could not cover the accumulated costs due to falling sales will no longer open. Often, large enterprises have a greater capacity to withstand COVID-19-like shocks, for example, if they have been able to make higher profit, gain easier access to finance, adapt to home delivery services, or diversify their businesses. Shocks in China, the EU, and the United States has had the greatest impact on the world trade, and as a result, developing countries have been affected as well.

This study shows how COVID-19 has affected small and medium-sized enterprises, based on recently published studies of World Bank enterprises in 13 countries. The study shows that enterprises of all size categories have suffered serious losses in many respects. Sales of small and medium-sized enterprises are declining more and their cash is depleting faster than those of large enterprises operating in the same sector and country. This is especially true for enterprises that depend on imports and exports, as well as companies operating in the service sector [1].

Specific attention is paid to how the pandemic has affected small and medium-sized enterprises (SMEs) in Russia. The indicators of SMEs in Russia are traditionally lower than in other major or actively developing economies of the world. The SME sector is not a growth driver in Russia [2]. Recently, there has been research on crisis management in small enterprises, including pandemic response [3-7], but there are few sources of information concerning low- and middle-income countries.

At the end of July 2020, the World Bank published new studies analysing enterprises from 13 different countries that had measured the impact of the virus on business, ranging from Italy and the Russian Federation to Albania and Zimbabwe. Despite their limitations, these surveys, along with the many other sources used in this study, show that the impact of the crisis on small enterprises is different compared to large enterprises [8].

There is thus a need to improve the anti-crisis management practices and mechanisms of SMEs, including addressing crises in the wave of the economic impact of the pandemic.

\section{Methodology}

The research methodology is based on the articles published by modern scientists on problems of crisis management in the period of the COVID-19 pandemic. Methods of statistical and economic analysis, expert assessments, methods of bankruptcy diagnosis, and forecasting were used. For the purpose of the study, statistical and analytical data from the World Bank, OECD, RBC, and the NAFI Analytical Centermare used. The impact of COVID-19 on SMEs in the federal districts of the Russian Federation is analysed using the data from the Federal Tax Service of the Russian Federation on the number of enterprises and employees in the SME sector in November of 2017-2021.

\footnotetext{
* Corresponding author: neklyudova.np@uiec.ru
} 


\section{Results}

Some sectors and regions with a disproportionately high share of small and medium-sized enterprises (SMEs) have been significantly affected by COVID - 19 restrictions. Although all enterprises and economic sectors have been directly or indirectly affected by government closure measures, some areas with a disproportionately high share of SMEs have been most seriously affected, at least initially.

This applies mainly to the tourism sector. It is estimated that international tourism will decrease by about $80 \%$ in 2020 [9]. Despite the fact that domestic tourism has developed relatively better, it remains significantly below the pre-Covid level. For example, the estimated decrease in domestic tourism in Spain and the United Kingdom, is 45-50\% in 2020 compared to 2019. Cultural events related to the closure of museums, theatres and cinemas have also been severely affected. A significant recovery of international tourist flows is not expected until 2021, and the achievement of the precrisis level is not expected until 2023 [9].

Besides the tourism sector, the economic sectors most directly affected by isolation measures, at least initially, include production of vehicles for the transport sector, construction, wholesale and retail trade, air transport, accommodation and catering services, real estate, professional services, and other personal services (e.g. hairdressers) (OECD, 2020). These sectors alone account for $40 \%$ of the total average employment in OECD countries [9].

SMEs ensure the majority of employment in the most affected sectors: on average, $75 \%$ in OECD countries and almost $90 \%$ in Greece and Italy. Microenterprises with fewer than 10 employees, those probably most endangered by cash shortages, employ about $30 \%$ of employees in these sectors and up to $60 \%$ in Greece and Italy [10].

Before the COVID-19 crisis, the financial situation of SMEs was generally favourable. Long-term interest rates were very low compared to historical standards, and monetary policy became increasingly flexible to compensate for relatively weak economic activity. Credit conditions were improved for SMEs with a low level of loan refusals and a gradual transition of loan portfolios to longer maturities.

In addition, digital tools contributed to the emergence of new online banks, some of which specialize in providing services to self-employed persons and owners of small businesses. In addition to bond issuing, asset-based financing also became an alternative source of financing for a growing number of SMEs. For example, in recent years, there has been a development of financial methods, such as leasing and hire purchase, as well as factoring, which allows SMEs to convert part of their assets into money to raise funds in the short term. In addition, the volume of venture capital investments for SMEs is growing, partly due to the government promoting the development of equity financing for SMEs [1].

Along with these positive trends, it is important to note that a third of all SMEs in the European Union continue to rely exclusively on domestic sources of income for their day-to-day operations and investments, which partly explains the slow credit growth in recent years. In addition, financing models still differ significantly between small and large SMEs, especially in Europe, with the former using more self-financing options and short-term loans, and fewer government subsidies and asset-based financing [11]. In addition, there are signs that the current crisis has a strong impact on equity, trade financing, and alternative financing, which is declining from the recent progress.

At this stage, small enterprises are still experiencing more serious financial difficulties compared to large ones. As a result, SMEs are more dependent on their internal financial resources and cash flows than large enterprises, both in the area of investment and in covering their current expenses, such as the remuneration of their employees.

These problems make SMEs more vulnerable to economic downturns and falling incomes than large enterprises are. This vulnerability is even more obvious for microenterprises that can rely only on bank financing or a limited number of alternative sources of financing.

However, the crisis caused serious problems for start-ups that had been established before its outbreak. Numerous surveys confirm that these young enterprises have been seriously affected by the crisis. More than $40 \%$ of new enterprises slipped into red zone (having only three-month cash or less to maintain their operations). Almost 3 out of 4 start-ups surveyed have experienced a decline in revenue and liquidity problems, and $41 \%$ of them needed to raise capital within the next three months [12].

There is growing evidence that the consequences of the COVID-19 pandemic for the self-employed and entrepreneurs were disproportionately negative. This negative impact was more significant than in the case of large enterprises, and in general in the case of employees. For example, an international study by Eurofound shows that the probability of becoming unemployed during the pandemic was higher among the self-employed (13\%) than among employees (8\%) [13]. This is consistent with the studies conducted in OECD countries, including e.g. in Australia, Germany, the United Kingdom and the United States [1].

In addition, there is evidence in OECD countries that subgroups of entrepreneurs, such as women and minorities, have been more affected, which partly reflects problems related to the access to finance, the economic sectors in which they usually work, and the increase in women's household responsibilities during the crisis.

The number of women entrepreneurs in the United States decreased by $10 \%$ between February and June 2020, while the number of male entrepreneurs decreased by $7 \%$ only [14]. Similarly, data from Germany show that female 
entrepreneurs are more than $30 \%$ more likely to lose income than male entrepreneurs are. There is also data from Canada and the UK that women entrepreneurs on average have reduced the number of hours worked about 1.5 times more than male entrepreneurs have. Many of these gender differences can be explained by differences in the sectors in which male and female entrepreneurs work. In addition, women are more likely to take on more household and care responsibilities during a pandemic [9], which limits their time for business activities.

The smaller the size of the enterprise and the earlier it is established, the more likely it is to refuse state support. Out of 32 OECD countries, 33\% of SMEs established 1-2 years ago received state support, compared to 39\% of enterprises established 2-3 years ago and 45\% of SMEs with at least five-year existence. Newly established enterprises were even less likely to receive support. Only $15 \%$ of SMEs that started their activities in 2020 have received state support [15].

SMEs have continued to struggle during the pandemic and the recovery phase: in 32 OECD countries, $42 \%$ - $96 \%$ of the surveyed SMEs in December 2020 said that additional support would be needed in the future. Enterprises which operate in countries with stricter deterrent measures are more likely to need further government support. For example, in New Zealand, a country with relatively mild deterrent measures, only 58\% of SMEs are expecting support [12]. By comparison, in Chile, the stringency index is twice as high as in New Zealand, which indicates stronger deterrent measures.

The indicators of SMEs in Russia are traditionally lower than in other major or actively developing economies of the world (see Table 1).

Table 1. Indicators of the SME sector in some countries

\begin{tabular}{|l|c|c|}
\hline & Share in GDP (\%) & Share of employed persons (\%) \\
\hline Russia & 20.8 & 27.0 \\
\hline USA & 56.0 & 52.0 \\
\hline Germany & 43.0 & 57.0 \\
\hline China & 60.0 & 83.0 \\
\hline Japan & 55.0 & 72.0 \\
\hline Malaysia & 39.0 & 48.0 \\
\hline Vietnam & 40.0 & 50.0 \\
\hline Uzbekistan & 56.9 & 78.0 \\
\hline Israel & 62.3 & 68.7 \\
\hline South Africa & 42.0 & 47.0 \\
\hline
\end{tabular}

Source: Special report of SME Ombudsman to the President of the Russia Federation [2].

According to various estimates (IMF, FAS of Russia, analytical centres), the SME sector is not a driver of growth in Russia. The share of the public sector, including state-owned companies, in the Russian economy is 40-70\%, while the share of the SME sector is 2.5 times lower. According to SME Ombudsman, the segment of medium-sized enterprises is the most undeveloped [2].

The sector of small and medium-sized enterprises in Russia has been stagnating for 10 years (see Table 2). Moreover, there are no processes of transformation of small enterprises into medium-sized ones.

Table 2. Indicators of the SME sector in Russia

\begin{tabular}{|l|c|c|c|c|c|c|c|}
\hline & 2010 & 2015 & 2016 & 2017 & 2018 & 2019 & 2020 \\
\hline Share of SME (\%) & 19.9 & 19.9 & 21.6 & 21.9 & 20.2 & 20.8 & 19.8 \\
\hline Share of employed persons in SME (\%) & 27 & 28 & 26 & 27 & 27 & 26 & 27 \\
\hline
\end{tabular}

Source: Special report of SME Ombudsman to the President of the Russia Federation [2]. 
The analysis of the Federal Tax Service on the number of SME and the number of persons working in the sector indicates that the number of enterprises itself has not decreased, it has even slightly increased, while the number of people employed decreased significantly, in the Far Eastern Federal District very drastically (see Fig.1).

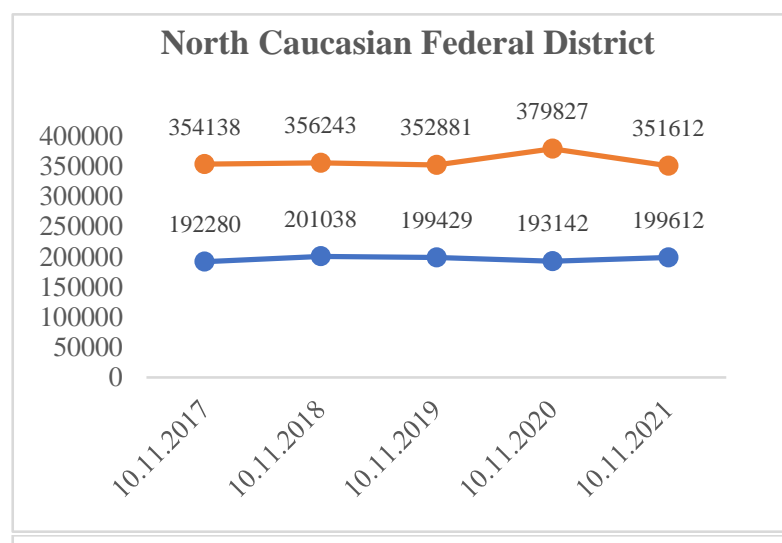

\section{Central Federal District}
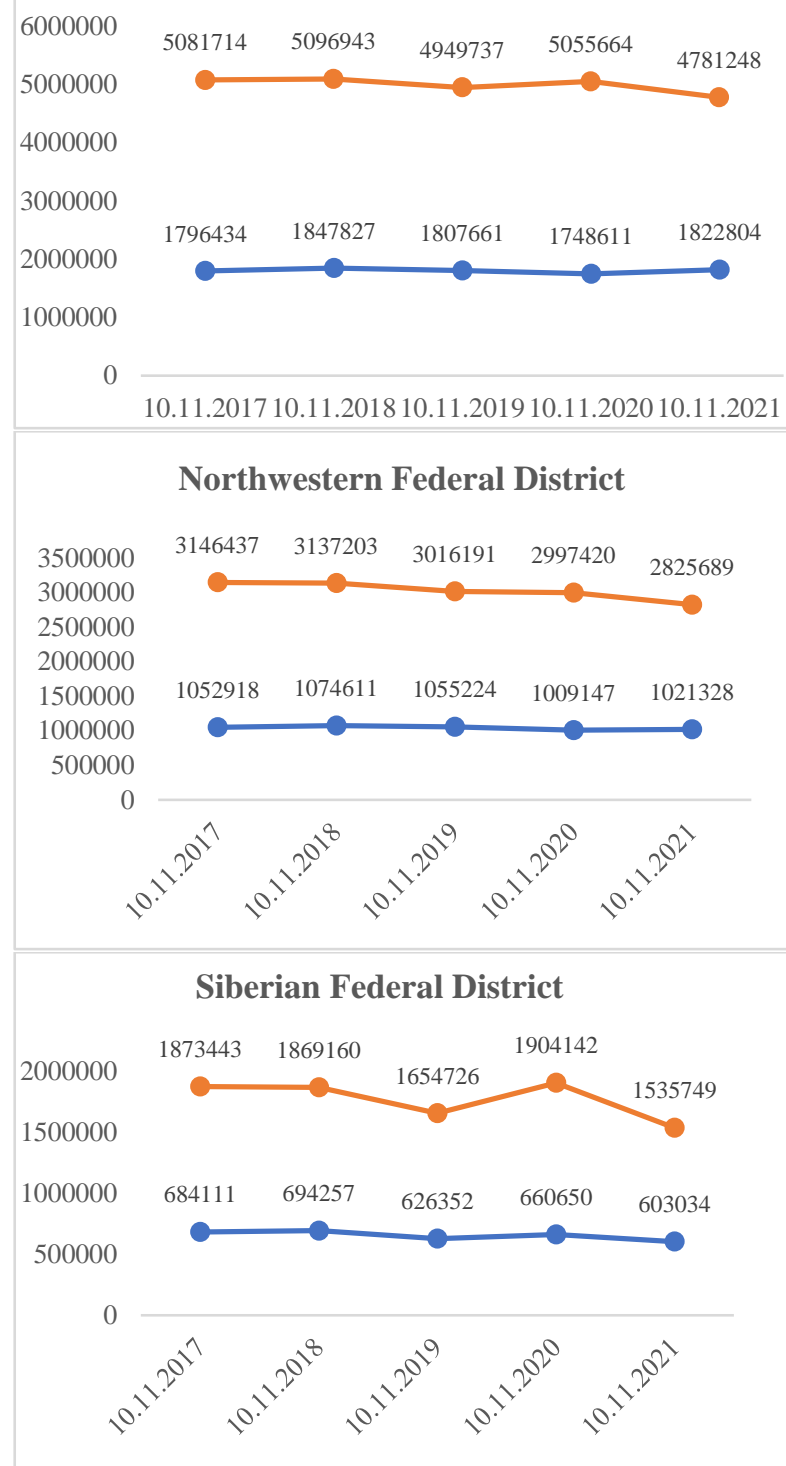

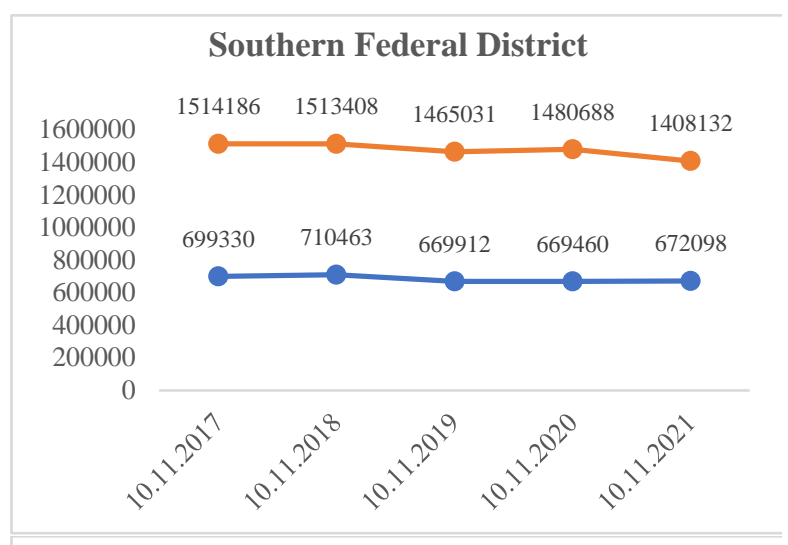

Volga Federal District

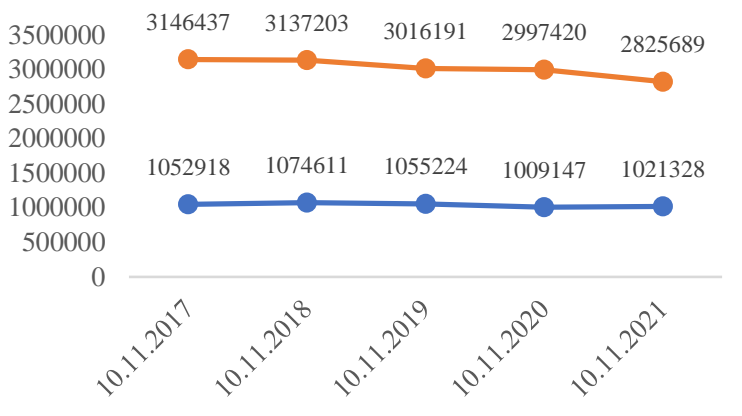

Ural Federal District

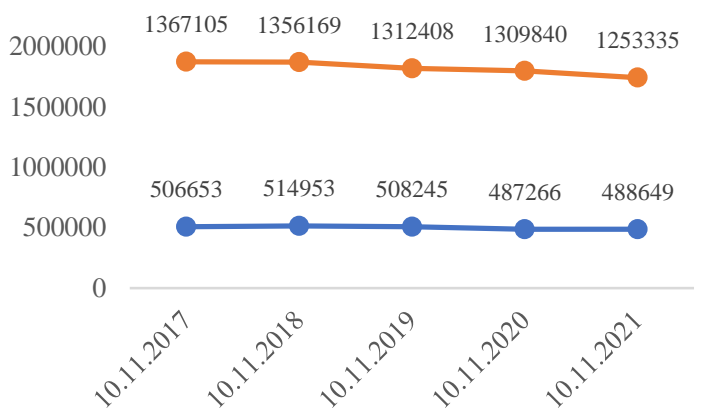

Far Eastern Federal District

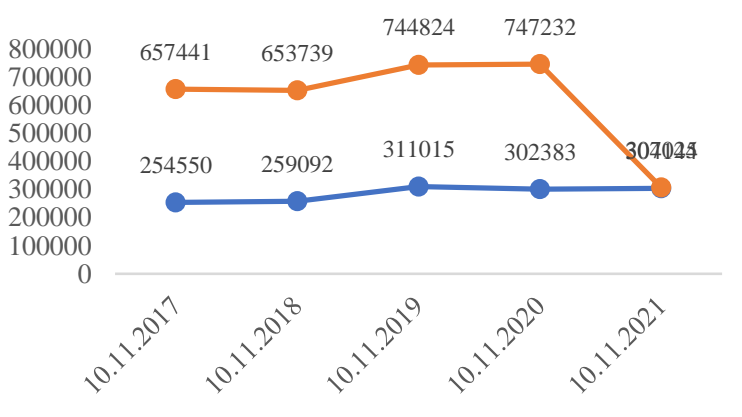

Figure 1. Number of SME (upper line) and employed in SME (lower line) in Russian federal districts Source: Author based on the data of Federal tax service of Russia [16]

This indicates that the main measures of state support should be aimed at maintaining employment. Statistical data on the impact of coronavirus on SMEs in districts is still limited. However, the current level of knowledge points to serious failures in the most affected regions. More than $36 \%$ of enterprises in the Russian Federation consider tax rates to be the 
biggest obstacle, compared to ca. $10 \%$ of enterprises in other countries. As for the access to finance, this was mentioned as the biggest obstacle $b \backslash 15 \%$ of enterprises. More than $8 \%$ of enterprises mention corruption as the biggest obstacle to their business activities [17].

According to Rosstat, $96 \%$ of SMEs are microenterprises with a 37\% share of the sector's turnover and a $29 \%$ share of employment, while small enterprises ensure $49 \%$ employment and account for $63 \%$ of the turnover. However, this information does not take into account informal workers and self-employed person, which represents ca. 21.3\% [18].

When non-working days were announced in the Russian Federation with the preservation of wages, this has led to the suspension in the activities of SMEs, especially those that were unable to switch to the online format. For example, in some travel agencies, after the introduction of anti-epidemic restrictions, revenue has decreased by $90 \%$. According to experts, the cost of one weekday of inactivity in a coffee shop in the centre of Moscow is 100-150 thousand roubles, while in the case of a clothing store, it ranges between 40 and 100 thousand roubles, and 60 - 80 million roubles in the case of a shopping centre [17].

Consumers postpone the purpose of non-essential goods and services, such as clothing, tourism, durable goods, etc. The drop in domestic demand directly hit the domestic suppliers. However, in the case of global value chains, consumer spending in high-income destination markets affects the demand for their exports.

At the same time, Mail.ru Group estimates that as of 8 July 2020, a third of medium-sized and small businesses did not receive payment for their services from customers during the pandemic [19]. According to the Federal Tax Service, 305.6 thousand individual entrepreneurs and 208 thousand legal entities ceased their activities as of 1 July 2020 [20].

\section{Discussion and Conclusion}

This study focuses on the situation of small and medium-sized enterprises (SMEs) with fewer than 100 employees in the wave of the pandemic. The study discusses the differences in the impact of the pandemic on enterprises of different size categories as well as their responses and how development finance can best support them in low-and middle-income countries [15]. Focusing on small firms makes sense for many reasons.

SMEs are the largest provider of employment and supply of goods and services in low-income countries; therefore, disruptions in this segment have serious social and social consequences for the poor and rural population. Moreover, longterm closure of small enterprises leads to the loss of intangible capital, skills, and innovative potential, which may result in a deep economic downturn in countries even long after the pandemic.

Thus, some of the development goals, whether aimed at supporting the incomes of the poor during an economic downturn, providing goods and services, or creating an appropriate framework for future recovery and development of industry, are directly related to the situation of SMEs during a crisis. The COVID-19 crisis has been the most serious global recession since the end of World War II. Physical distancing, lockdown and restrictive measures introduced worldwide to stop the spread of the pandemic have led to unprecedented shocks to the business environment both in OECD and non-OECD countries. This recession was even more sudden than the financial crisis of 2008-2009. GDP declined significantly in all major OECD countries in the first two quarters of 2020.

In different countries, the stricter the isolation measures, the stronger the initial decline in economic growth has been. Facing a significant health crisis, many governments reacted by adopting various measures of social distancing (isolation) to prevent the spread of the virus, which has also significantly reduced economic activity.

As restrictions related to the economic activity were eased in the summer, GDP partly recovered, but remained below the pre-crisis level. While the total GDP in the OECD region was 11.6\% lower in Q2 of 2020 than Q2 of 2019, the gap narrowed to 3.8\% in Q3 of 2020. Nevertheless, due to the emergence of new options in recent months, the pace of recovery slowed down, and in Q4 of 2020, the GDP level remained 3.4\% lower than in the previous year [12].

At the time of implementing this study, the prospects for overcoming the SME crisis continued to improve, as evidenced by recent economic forecasts, but they remain uncertain and uneven across countries. The brighter prospects are mainly related to the gradual introduction of effective vaccination, support for macroeconomic policies, especially in the United States (USA) and the EU, and signs that the economy is coping better with measures to stop the spread of the virus. Global economic activity has now returned to its pre-pandemic level, but it will remain weaker at the end of 2022 than before the pandemic. There are also noticeable differences in the impact of the crisis and the pace of recovery in different countries. The recovery is still affected by the risks of new outbreaks of the virus with the appearance of its variants in different places and the problems associated with vaccine rollout to a sufficient extent.

To survive the pandemic, SMEs need grants, not loans. Most simply do not apply to banks for loans, despite record low-interest rates. However, not all governments have a budget for grant support. Eight out of 10 enterprises of all size categories expect some form of government help in higher-income countries, such as Cyprus [20]. In low-income countries, such as Georgia or Moldova, small public funds are allocated to larger enterprise. In Africa, even fewer people expect government support; most governments in low-income countries have not taken any measures to support SMEs. 
The combination of limited budget and already high corporate debt creates the greatest risks for countries with aboveaverage income.

The main measures that can contribute to economic growth include the reduction of tax burden on enterprises; limiting the growth in tariffs for infrastructure services and raw materials monopolies and reduction of administrative pressure on business. In the short term, governments are recommended firstly to ease restrictions to attracting employees from neighbouring countries; secondly, to compensate SME expenses for PCR tests and personal protective aids. In the case of lockdown, governments should pay a $100 \%$ for employee downtime at the expense of the state directly, without necessary participation of the employer.

The COVID-19 pandemic is a unique crisis, affecting enterprises in many ways: supply (reduced labour supply because employees stay at home, lack of resources, disrupted supply chains); demand (reduced demand from lost and returning consumers, precautions, cautious investors); uncertainty (inability to count on a future income stream that justifies, for example, the replacement of employees or equipment); and unavailability of finance.

The article was prepared under the plan of Institute of Economics of the Ural Branch of RAS for 2021-2023.

\section{References}

1. S. Adžić, J. Al-Mansour. Business analysis in the times of COVID-19: Empirical testing of the contemporary academic findings. Management Science Letters. 11(1), 1-10 (2021)

2. Institute for the Economics of Growth P. A. Stolypin. Special report of SME Ombudsman to the President of the Russian Federation - 2021 [online]. Available at: http://doklad.ombudsmanbiz.ru/2021/7.pdf (2021)

3. M. Mandviwalla, R. Flanagan. Small business digital transformation in the context of the pandemic. European Journal of Information Systems. 1-17 (2021) doi:org/10.1080/0960085X.2021.1891004

4. Kuckertz, L. Brändle, A. Gaudig, S. Hinderer, C. Arturo, M. Reyes, A. Prochotta, K. M.Steinbrink, E. S. C. Berger. Startups in times of crisis-A rapid response to the COVID-19 pandemic. Journal of Business Venturing Insights. 13, e00169 (2020) doi:org/10.1016/j.jbvi.2020.e00169

5. J. C. Alves, T. C. Lok, Y. Luo, W. Hao. Crisis Management for Small Business during the COVID-19 outbreak: Survival, resilience and renewal strategies of firms in Macau. Research Square. 1-29 (2020)

6. I. J. Akpan, D. Soopramanien, D. H. Kwak. Cutting-edge technologies for small business and innovation in the era of COVID-19 global health pandemic. Journal of Small Business \& Entrepreneurship. 1-11 (2020)

7. V. Ratten. Coronavirus (covid-19) and entrepreneurship: changing life and work landscape. Journal of Small Business \& Entrepreneurship. 32(5), 503-516 (2020)

8. I. Adian, D. Doumbia, N. Gregory, A. Ragoussis, A.Reddy, J. Timmis. Small and medium enterprises in the pandemic [online]. Available at: https://openknowledge.worldbank.org/bitstream/handle/10986/34552/Small-andMedium-Enterprises-in-the-Pandemic-Impact-Responses-and-the-Role-of-Development-Finance.pdf?sequence=1 (2020)

9. OECD. Coronavirus (COVID-19): SME Policy Responses [online]. Available at: http://www.oecd.org/coronavirus/policy-responses/coronavirus-covid-19-sme-policy-responses-04440101/ (2020)

10. J. Juergensen, J. Guimón, R. Narula. European SMEs amidst the COVID-19 crisis: assessing impact and policy responses. Journal of Industrial and Business Economics. 47, 499-510 (2020)

11. A. W. Bartik, M. Bertrand, Z. B. Cullen, E. L. Glaeser, M. Luca, C. T. Stanton. How are small businesses adjusting to COVID-19? Early evidence from a survey (No. w26989). National Bureau of Economic Research [online]Available at: https://www.nber.org/system/files/working_papers/w26989/w26989.pdf (2020)

12. J. Sheth. Business of business is more than business: Managing during the Covid crisis. Industrial Marketing Management. 88, 261-264 (2020)

13. Eurofound. European Working Conditions Survey [online]. Available at: https://www.eurofound.europa.eu/surveys/2020/european-working-conditions-survey-2020 (2020)

14. T. Ritter, C. L. Pedersen. Analyzing the impact of the coronavirus crisis on business models. Industrial Marketing Management. 88, 214-224 (2020)

15. H. He, L. Harris. The impact of Covid-19 pandemic on corporate social responsibility and marketing philosophy. Journal of Business Research. 116, 176-182 (2020)

16. Federal tax service of Russia. Unified Register of Small and medium-sized businesses [online]. Available at: https://ofd.nalog.ru/ (2021) 
17. RBC. Research on the impact of the COVID-19 pandemic on Russian business [online]. Available at: https://sapmybiz.rbc.ru/RBK_Issledovanie_vliyaniya_pandemii_COVID_19_na_rossiyskiy_biznes.pdf (2020)

18. NAFI Research Centre. The impact of the coronavirus epidemic on business and the need for state support [online]. Available at: https://nafi.ru/projects/predprinimatelstvo/rossiyskiy-biznes-i-koronavirus-chast-1-predprinimateli-ovliyanii-epidemii-na-ikh-biznes-i-o-potreb/ (2020)

19. Mail.ru Group. Research by Mail.ru for business [online]. Available at:https://biz.mail.ru/blog/contractors-survey/ (2020)

20. Federal tax service of Russia. Statistics on state registration of legal entities and sole proprietors in the Russian Federation as a whole [online]. Available at: https://www.nalog.ru/rn77/related_activities/statistics_and_analytics/regstats/ (2020)

21. J. B. Carnevale, I. Hatak. Employee adjustment and well-being in the era of COVID-19: Implications for human resource management. Journal of Business Research. 116, 183-187 (2020) 